\title{
Hepatitis B Virus Surface Antigen Measurement
}

National Cancer Institute

\section{Source}

National Cancer Institute. Hepatitis B Virus Surface Antigen Measurement. NCI

Thesaurus. Code C64850.

A determination of the presence of hepatitis B virus surface antigen. 